\section{Selection parameters of a new "coerulea" multiflora hybrid: Cattlianthe aurora's blue pride}

\section{Nelson Barbosa Machado Neto ${ }^{1^{*}}$}

Abstract: Cattlianthe Aurora's Blue Pride is a new hybrid with lavender-blue flower, higher floral count than Cattleya Memoria Jack Hayden and larger than Cattlianthe Portia Baronesa. For the first time, a floral trait is being used in a documented scientific approach to help in the selection of superior plants in a population.

Keywords: Plant breeding, orchid hybrid, blue flower.

\section{INTRODUCTION}

Cattleya is a large orchid genus, with 102 species, 95 of which are found in Brazil (Flora do Brasil 2017). Cattleya and its hybrids (Cattleya hybrid group) are among the most valuable flowers, but their development is slow (3-7 years) in comparison with the genetic material of Phalaenopsis, Dendrobium or Oncidium, which have a relatively fast development (1-3 years) of new materials (De and Medhi 2015, Colombo et al. 2017, Stulzer et al. 2019). In Brazil, the ornamental flower market is demanding selected new plant material, in particular of orchids and other tropical species (Junqueira and Peetz 2014, Cardoso et al. 2016).

Most breeding programs are focused on the development of well-shaped white semi-alba, pink, yellow and red flowers, derived from several parents. Almost all Cattleya species have bluish types called coerulea, except for the yellow populations of Cattleya aurea, C. Iuteola (Withner 1988), the red lines derived from - Brassavola, Rhyncholaelia (Withner 1998) and the Cattleya (Van den Berg et al. 2009) formerly classified as Sophronitis (Withner 1993). Still, few Cattleya breeding programs are selecting for blue tones and multiflora inflorescences.

Since 1999, a breeding program has been developed in the Orquidário Aurora, mainly for Cattleya hybrids, focused on small flowering plants. Some crosses of new combinations with Guarianthe bowringiana and its hybrids were performed, preferring those with bluish flowers, because they carry traits of multiflora plants.

For selection, a genetic parameter is being sought to be used as a tool to improve the quality of the flower, which should have a rounded shape, with harmoniously arranged floral segments (sepals and petals) without spaces between them.
Crop Breeding and Applied Biotechnology 19(4), 487-490, 2019 Brazilian Society of Plant Breeding. Printed in Brazil http://dx.doi.org/10.1590/1984$70332019 v 19 n 4 c 70$ 


\section{GENETIC ORIGIN AND DEVELOPMENT}

The hybrid Cattlianthe Aurora's Blue Pride was registered by the Royal Horticultural Society, no. 24597, in November 2014. It was derived from a cross of Cattlianthe Portia "Baronesa" (a bluish clone of the cross between Cattleya labiata and Guarianthe bowringiana) as mother parent and the pollen of Cattleya Memoria Jack Hayden, another blue material [a cross between Cattleya warneri and Cattleya Cornelia (Cattleya labiata x Cattleya pumila)]. The resulting capsule developed for nine months and was collected at the first signs of maturation. It was then inserted in a paper envelope, which was placed on a layer of silica gel in a box until complete maturation. Due to the low compatibility between Guarianthe and Cattleya, a low number of viable seeds were produced that could be germinated.

Seeds were disinfected as described by Machado Neto and Custódio (2005) with $5 \mathrm{~g} \mathrm{~L}^{-1}$ sodium dichloroisocyanurate with $100 \mu \mathrm{L}$ Tween 80 as wetting agent. They were left for $10 \mathrm{~min}$ in this solution and mixed by inverting the tubes by hand during this period. Thereafter, seeds were washed twice in distilled autoclaved water and sown on $1 / 2$ strength MS medium (Murashige and Skoog 1962), with $20 \mathrm{~g} \mathrm{~L}^{-1}$ sucrose and $8 \mathrm{~g} \mathrm{~L}^{-1}$ agar. The $\mathrm{pH}$ of the medium was adjusted to 5.6, autoclaved and distributed on petri dishes (diameter $60 \mathrm{~mm}$ ). After 60 days, the seedlings were transferred into flasks and allowed to grow for 90 days and then replanted in other flasks. This was repeated until the seedlings reached a height of $\geq 15 \mathrm{~mm}$. Seedlings were removed from the flasks, rinsed carefully to wash off any agar debris and immersed in a solution containing $2 \mathrm{~g} \mathrm{~L}^{-1}$ methyl tiophanate for $1 \mathrm{~h}$. The solution was drained and the seedlings allowed to dry overnight.

The seedlings were planted in community pots on sphagnum moss as substrate and fertigated weekly with a hydro soluble 20:20:20 NPK fertilizer at $1 \mathrm{~g} \mathrm{~L}^{-1}$. If pests or diseases were observed, the necessary care was taken. After one year, the plants were transferred to individual pots $(5 \mathrm{~cm})$, filled with $1 / 3$ gravel and a fine texture pine bark $(<5 \mathrm{~mm})$ mixture with chopped Sphagnum moss $(1: 1, \mathrm{v}: \mathrm{v})$ and maintained there for almost another year. When the plants were $15 \mathrm{~cm}$ tall, they were transferred to larger pots with $1 / 3$ gravel and medium pine bark granulometry $(<12 \mathrm{~mm})$ until flowering (at least 2 more years).

\section{Plant material}

Plants of Cattlianthe Aurora's Blue Pride are medium to large sized plants (30-40 cm high), mostly unifoliate. The root system resembled more the Guarianthe bowringiana parent with many fine roots than the other parent with few large roots. The five to nine bluish-lavender flowers (Figure 1B) are medium to large, with large petals. The labellum is dark lavender blue, similar to that of $G$. bowringiana. The flower sizes of the descendant and parent plants are shown in Table 1.

\section{Selection traits}

Although many criteria are relevant for selection, e.g., earliness and color (Cardoso 2010, Cardoso et al. 2016, Colombo et al. 2017), no genetic parameters of the flower have yet been estimated or defined for the selection of superior clones.

Flowers of 13 plants of the hybrid population, with a good flower shape and display on the stem, were selected as parent plants and measured (Figure 1C, Table 1).

Based on (1), the genetic gain with selection was calculated to decide which flower trait would be preferable for selection.

$$
G_{s}=h^{2} \times S D
$$

Table 1. Flower measurements of Cattlianthe aurora's blue pride and its parents

\begin{tabular}{lcccc}
\hline Cattlianthe & $\begin{array}{c}\text { Flower diameter } \\
(\mathrm{mm} \pm \mathrm{SE})\end{array}$ & $\begin{array}{c}\text { Petal width } \\
(\mathrm{mm} \pm \mathrm{SE})\end{array}$ & $\begin{array}{c}\text { Dorsal sepal width } \\
\text { (mm } \pm \mathrm{SE})\end{array}$ & $\begin{array}{c}\text { Labellum mid lobe width } \\
\text { (mm } \pm \mathrm{SE})\end{array}$ \\
\hline Cattlianthe Portia “Baronesa' & $99.87 \pm 5.19 \mathrm{c}^{\S}$ & $35 \pm 2.98 \mathrm{~b}$ & $14.12 \pm 2.64 \mathrm{~b}$ & $33.87 \pm 3.91 \mathrm{ab}$ \\
Cattleya Memoria Jack Hayden & $167.01 \pm 1.86 \mathrm{a}$ & $79.29 \pm 0.88 \mathrm{a}$ & $54.20 \pm 0.60 \mathrm{a}$ & $30.11 \pm 0.33 \mathrm{~b}$ \\
Cattlianthe Aurora's Blue Pride & $116.35 \pm 10.70 \mathrm{~b}$ & $42.41 \pm 3.52 \mathrm{~b}$ & $16.18 \pm 3.54 \mathrm{~b}$ & $38.06 \pm 3.94 \mathrm{a}$ \\
\hline
\end{tabular}

${ }^{5}$ Means followed by different letters in the column are statistically different by Bonferoni t test $(p<0.05)$. 
where $G_{s}$ is the gain with selection, $h^{2}$ the trait heritability and $S D$ the selection differential, calculated as the difference between the mean of the original population and that of the selected plants.

Heritability was calculated as in (2):

$$
h^{2}=\frac{\sigma_{F}^{2}-\sigma_{E}^{2}}{\sigma_{F}^{2}}
$$

where $\sigma_{F}^{2}$ is the variance of the hybrid population and $\sigma_{E}^{2}$ the environmental variability measured as the mean of the two parent plants.

The percentage of genetic gain $\left(G_{5 \%}\right)$ was calculated as in (3):

$$
\left.G_{s \%}=\left(\frac{G_{s}}{\bar{X}}\right) \times 100\right)
$$

where $G_{S}$ is the gain with selection and $\bar{X}_{0}$ the mean of the initial population.

The mean of the superior population $\left(\bar{X}_{s}\right)$ was calculated as in (4):

$$
\bar{X}_{s}=\bar{X}_{0}+G_{s}
$$

These values were calculated for natural flower diameter (D), petal width (PW) and labellum mid lobe width (LML). The dorsal sepal (DS) was measured but not used as selection criterion. All variables, in the parental clones and in the offspring, were compared by the Bonferroni " $t$ " test $(p \leq 0.05)$.

The natural flower diameter $\left(h^{2}=0.87\right)$ was used as a selection factor for being positively related with DS and LML, with $G_{5 \%}$ of 19.69 and 3.06, respectively. However, it

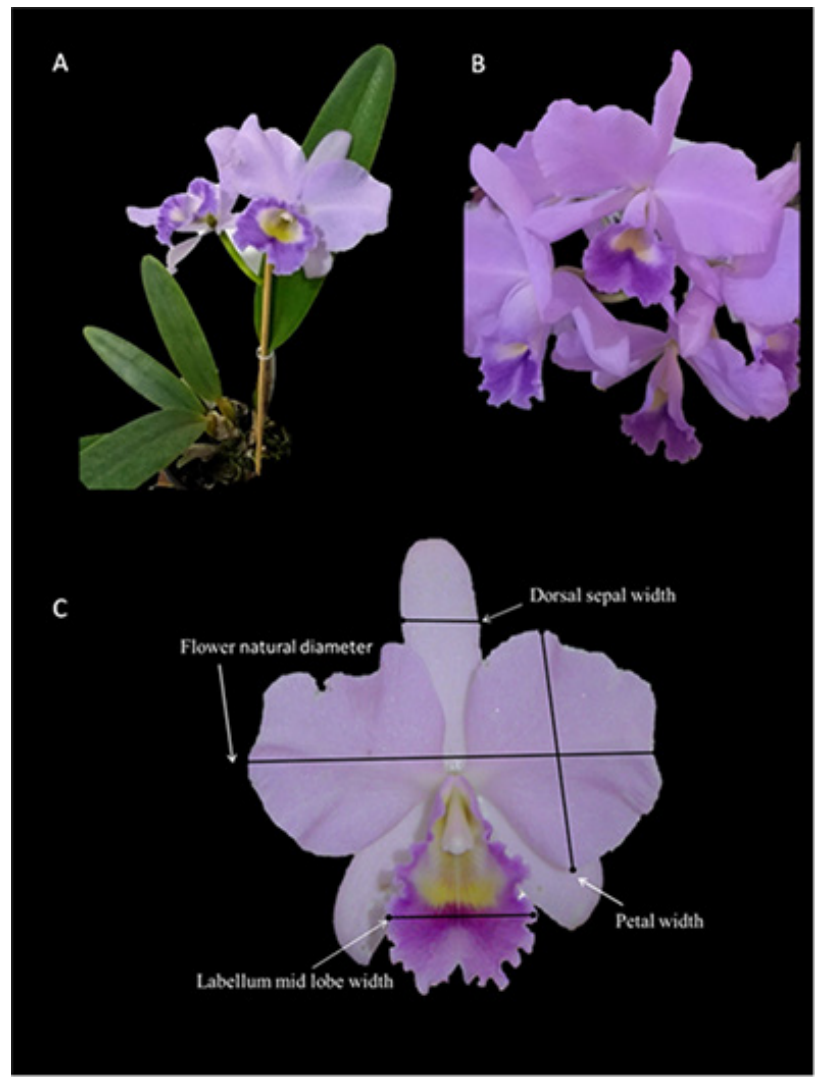

Figure 1. A - First flowering of a seedling of Cattlianthe Aurora's Blue Pride; B - Mature inflorescence; and C - Isolated flower showing where the measures were taken. was negatively related with PW (-6.96\%), which means an unbalanced flower shape, resulting in poor flower quality. On the other hand, when using either PW or LML (Table 2), all traits but diameter were positively impacted. Only small gains were obtained for diameter (7.05 and 7.81\% for PW

Table 2. Genetic parameters for selection of Cattlianthe Aurora's Blue Pride and their impact on the selection differential (SD), gain

\begin{tabular}{|c|c|c|c|c|c|c|}
\hline Selection criteria & Heritability $\left(h^{2}\right)$ & & $S D^{*}$ & $G_{s}^{* *}$ & $G_{s} \%^{\S}$ & $\bar{X}_{s}^{\S \S}$ \\
\hline \multirow{4}{*}{ Diameter (mm) } & \multirow{4}{*}{0.87} & D & 15.31 & 13.28 & 11.60 & 129.63 \\
\hline & & Dsp & 3.49 & 2.47 & 19.69 & 18.64 \\
\hline & & PW & -1.41 & -0.86 & -6.96 & 41.55 \\
\hline & & LML & 0.94 & 0.47 & 3.06 & 38.53 \\
\hline \multirow{4}{*}{ Petal Width (mm) } & \multirow{4}{*}{0.61} & $D$ & 9.31 & 8.07 & 7.05 & 124.43 \\
\hline & & SD & 4.59 & 2.80 & 22.64 & 18.64 \\
\hline & & PW & 3.49 & 2.47 & 19.69 & 45.21 \\
\hline & & LML & 4.61 & 2.33 & 14.98 & 40.39 \\
\hline \multirow{4}{*}{ Labellum mid lobe width (mm) } & \multirow{4}{*}{0.50} & $\mathrm{D}$ & 10.31 & 8.94 & 7.81 & 125.29 \\
\hline & & SD & 3.59 & 2.19 & 17.70 & 18.17 \\
\hline & & PW & 2.82 & 1.99 & 15.93 & 44.60 \\
\hline & & LML & 6.94 & 3.51 & 22.56 & 41.57 \\
\hline
\end{tabular}
with selection (GS), percent gain with selection (GS\%) and mean of improved population $\left(X_{s}\right)$ of flower traits such as diameter (D), dorsal sepal (Dsp), petal width (PW) and labellum mid lobe width (LML)

* Selection differential, ${ }^{* *}$ Gain with selection, ${ }^{\S}$ Percent gain with selection and ${ }^{\S \S}$ Improved population mean 
or LML, respectively), whereas with these selection factors PW or LML, rather small, but well-balanced flowers in all structures could be developed, improving the flower appearance.

In the scientific literature, this is the first description of a parameter to select genetically superior clones from a cross within the Cattleya Hybrid group.

\section{SELECTION OF SUPERIOR CLONES, CONSERVATION AND MULTIPLICATION}

The superior clones, selected based upon the criteria described above, were separated and included as parents in our breeding program and intercrossed. The resulting seeds were sown (Figure $1 \mathrm{~A}$ ), generating a superior population to select better clones. The plants are currently maintained in black plastic pots filled with broken macadamia nut shells, in a shadehouse, fertigated once a week with a 30-10-10 NPK $\left(0.22 \mathrm{~g} \mathrm{~m}^{-2}\right)$ and supplemented fortnightly with either $0.11 \mathrm{~g} \mathrm{~m}^{-2} \mathrm{KCl}$ or $\mathrm{MgSO}_{4}$. The commonly used phytosanitary practices for orchid cultivation were applied. The plants of Cattlianthe Aurora's Blue Pride are maintained in the private Orquidário Aurora, located close to the state highway SP483, in Taciba, São Paulo.

\section{REFERENCES}

Cardoso JC (2010) Laeliocattleya 'Brazilian Girl Rosa': cultivar de orquídea para cultivo em vaso. Horticultura Brasileira 28: 378-381.

Cardoso JC, Martinelli AP and Teixeira da Silva JA (2016) A novel approach for the selection of Cattleya hybrids for precocious and seasonindependent flowering. Euphytica 210: 143-150.

Colombo RC, Hoshino RT, Ferrari EAP, Alves GAC and Faria RT (2017) Cattleya forbesii x Cattleya bowringiana: a new hybrid of Cattleya orchid. Crop Breeding and Applied Biotechnology 17: 184-186.

De LC and Medhi RP (2015) Orchid-a diversified component of farming systems for profitability and livelihood security of small and marginal farmers. Journal of Global Bioscience 4: 1393-1406.

Flora do Brasil (2017) Flora do Brasil 2020 em construção. Jardim Botânico do Rio de Janeiro. Available at <http://floradobrasil.jbrj.gov.br/reflora/ listaBrasil/ConsultaPublicaUC/ResultadoDaConsultaNovaConsulta. do\#CondicaoTaxonCP >. Accessed on March 01, 2019

Junqueira AH and Peetz MDS (2014) O setor produtivo de flores e plantas ornamentais do Brasil, no período de 2008 a 2013: atualizações, balanços e perspectivas. Revista Brasileira de Horticultura Ornamental 20: 115-120.
Machado Neto NB and Custódio CC (2005) A medium for non-commercial sowing of orchid seed. Selbyana 26: 316-317.

Murashige T and Skoog F (1962) A revised medium for rapid growth and bio assays with tobacco tissue cultures. Physiologia Plantarum 15: 473-497.

Stulzer GCG, Hoshino RT, Suzuki ABP, Alves GAC and Faria RT (2019) Primary hybrid of Cattleya forbesii x Cattleya loddigesii, a new Brazilian orchid. Crop Breeding and Applied Biotechnology 4: 364-367.

Van den Berg C, Higgins WE, Dressler RL, Whitten WM, Soto-Arenas MA and Chase MW (2009) A phylogenetic study of Laeliinae (Orchidaceae) based on combined nuclear and plastid DNA sequences. Annals of Botany 104: 417-430.

Withner CL (1988) The Cattleyas and their relatives: a book in six parts. Vol. I, The Cattleyas. Timber Press, Oregon, 147p.

Withner CL (1993) The Cattleyas and their relatives: a book in six parts. Vol. III, Schomburgkia, Sophronitis, and other South American genera. Timber Press, Oregon, 180p.

Withner CL (1998) The Cattleyas and their relatives: a book in six parts. Vol. V. Brassavola, Encyclia, and other genera of México and Central America. Timber Press, Oregon, 198p. 